\title{
Başlangıcından Bugüne Bilgi Dünyası Dergisi'nin Bibliyometrik Profili
}

\section{Bibliometric Profile of Information World Since the Beginning}

\author{
Zehra TAŞKIN*ve Tolga ÇAKMAK**
}

\begin{abstract}
Öz
Türkiye'de kütüphanecilik ve bilgibilim alanı literatürünün gelişmesinde Üniversite ve Araştırma Kütüphanecileri Derneği'nin (ÜNAK) resmi yayın organı olan Bilgi Dünyası dergisinin katkısı bilinmektedir. 2000 yılından bu yana Nisan ve Ekim aylarında olmak üzere yılda iki defa yayımlanan Bilgi Dünyası dergisi üniversite ve araştırma kütüphaneleri ile birlikte, bilgibilim, bilgi hizmetleri, bilgi ve belge yönetimine ilişkin sorunları inceleyen ve çözüm önerileri sunan makaleleri yayımlamayı amaçlamaktadır. Çalışmamızda da Bilgi Dünyası dergisinde yayımlanan 104 makale ve 60 görüş bibliyometrik özellikleri açısından analiz edilmektedir. Analiz sonuçlarına göre yayımlandığı ilkyıldan bu yana geçen süre gözönüne alındığında son üçyılda yayımlanan hakemli makale sayısının diğer yıllara oranla daha yüksek oranda olduğu görülmüştür. Makalelerin konu dağılımı olarak ise çoğunlukla bilgi merkezleri ile ilgili olduğu saptanmıştır. Çalışma sonuçlarında Bilgi Dünyası dergisi örneğinden hareketle Türkiye'deki kütüphanecilik alanında yapılan çalışmalara yönelik detaylı bir atıf analizi çalışmasının gerekliliği önerilmektedir.
\end{abstract}

Anahtar Sözcükler: Bibliyometri, Bilgi Dünyası dergisi, ÜNAK

\section{Abstract}

It is known that Information World is one of the major periodicals which is published by Association of University and Research Librarians for improvement of Library and Information Science literature in Turkey. Published two times in a year Information World Journal aims at publishing papers that present specific problem solutions and investigate developments and problems in the field of Library and Information Science. With this scope in mind, 104 research papers and 60 opinions letters were analyzed it is seen that the number of research papers that were published in the last three years was greater than the number of research papers that were published in other years. According to subject distribution, analysis results show that most of the research papers are about information centers. In conclusion part of the study, among others, it is recommended by authors of the study that detailed citation analysis and citation maps of Library and Information Science in Turkey should be studied thoroughly.

Keywords: Bibliometrics, Information World journal, UNAK

\footnotetext{
* Arş. Gör..; Hacettepe Üniversitesi Bilgi ve Belge Yönetimi Bölümü Beytepe 06800-Ankara (ztaskin@hacettepe.edu.tr)

** Arş. Gör..; Hacettepe Üniversitesi Bilgi ve Belge Yönetimi Bölümü Beytepe 06800-Ankara (tcakmak@hacettepe.edu.tr)
} 


\section{Giriş}

Teknolojik koşullardaki yenilikler, yeni buluşlar ve kuramsal boyutta oluşturulan bilgilerin uygulama alanına etkin ve hızlı bir şekilde aktarılmasıyla bilim dallarında birikimli bir ilerlemenin yaşanması mümkün olmaktadır. Bu doğrultuda ilgili alanda yayımlanan kitaplar, bilimsel makaleler, düzenlenen toplantılar ve bu toplantılarda sunulan bildiriler önemli işlevlere sahiptir.

Günümüz koşullarında bilim dallarına bakıldığında, daha önce yapılan bilimsel çalışmalardan da yararlanılarak yeni gelişmelerin ve hızlı bir bilgi artışının yaşandığı dikkati çekmektedir. Bu noktada bilimsel alanda üretilen bilgilerin uygulama alanı ile paylaşılmasını sağlayan kurumlar; çıkardıkları yayınlar, düzenledikleri ulusal ve uluslararası kapsamdaki toplantılarla kuramsal boyutta üretilen bilgilerin ilgili alana katkı sağlayacak bir şekilde aktarılmasına yardımcı olmaktadırlar.

Bilimsel çalışmaların ve teknolojik gelişmelerin yanı sıra bilim dallarının gelişmesine katkı sağlayan bir diğer unsur ise o alanla ilgili mesleki dernekler/vakıflardır. Ulusal ya da uluslararası boyutta ilgili oldukları alanın sorunlarını çözmek amacıyla kurulan mesleki dernekler, günümüzde düzenledikleri konferanslar, seminerler, çalıştaylarla birlikte yayımladıkları kitaplar ve bilimsel dergilerle de bilginin toplumsallaşması görevini üstlenmektedirler. Bu bağlamda mesleki derneklerin çıkardıkları bilimsel dergiler, alanla ilgili literatürün gelişmesi ve alanın güncel konularının hedef kitlelere aktarılması açısından önemli olmaktadır. Çeşitli örneklerini hem ulusal hem de uluslararası kapsamda gördüğümüz birçok mesleki dernek yayımladıkları ve çeşitli indekslerde dizinlenen bilimsel dergilerle ön plana çıkmakta ve ilgili oldukları alanın gelişimine çok boyutlu bir katkı sağlamaktadır.

Bilgibilim ve kütüphanecilik alanında da diğer bilim dallarında olduğu gibi birçok dernek, mesleki oluşum bulunmakta ve bu oluşumlar çeşitli kapsamlarda yayınlar yapmaktadırlar. Türkiye'de 1950'li yılların ortalarından itibaren ortaya çıkan bilgibilim ve kütüphanecilik alanındaki mesleki dernekler ve oluşumlar; okul kütüphaneleri, halk kütüphaneleri, üniversite ve araştırma kütüphaneleri, arşivler ve dokümantasyon merkezleri gibi alt alanların gelişimini sağlamaya yönelik girişimlerde bulunmuşlar, günümüzde de çıkardıkları bilimsel dergiler ve düzenledikleri etkinliklerle bu girişimlerini devam ettirmektedirler.

Türkiye'deki bilgibilim ve kütüphanecilik alanına katkı sağlayan derneklerin gelişimine kısaca göz atacak olursak 1949 yılında Adnan Ötüken'in öncülüğünde Türk Kütüphaneciler Derneği'nin (TKD) kurulduğu görülmektedir. Hedef kitlesini genel olarak bütün kütüphanelerin, kütüphanecilerin ve kütüphanecilik alanının oluşturduğu TKD, 1952 yılından itibaren üç ayda bir olarak yayımladığı Türk Kütüphaneciliği dergisiyle ulusal anlamda bilimsel literatürün oluşmasına ve gelişmesine katkıda bulunmakta; sahip olduğu alt gruplarla birlikte düzenlediği çeşitli etkinliklerle de alanın Türkiye'de 
tanınmasına ve sorunlarının çözümlenmesine yardımcı olmaya çalışmaktadır (Türk Kütüphaneciler Derneği, 2010; Türk Kütüphaneciliği, 2010).

Türkiye'de kütüphanecilik alanındaki mesleki dernek ve oluşumların gelişiminde önemli bir oluşum da Okul Kütüphanecileri İstanbul Grubunun (OKIG) 2002 yılında oluşturulması ve okul kütüphanelerine yönelik olarak mesleki paylaşım platformlarının oluşturulmasıdır. Bu kapsamda OKIG okul kütüphanelerine yönelik sorunların çözümlenmesi, mesleki paylaşımların ve iş birliklerinin gerçekleştirilmesi konularında etkinlikler düzenleyerek mesleğin gelişimine katkı sağlamaktadır (Torun, 2003, s.57).

Üniversite ve araştırma kütüphaneleri kapsamında ise 1992 yılında Üniversite ve Araştırma Kütüphanecileri Derneği (ÜNAK) kurulmuştur. Genel anlamda üniversite ve araştırma kütüphanelerinin, dokümantasyon ve enformasyon merkezlerinin ve özel kütüphanelerin, hızla değişen ve gelişen teknolojiye bağlı olarak ortaya çıkan sorunlarını incelemek ve bu sorunları çözümlemek için gereklilikleri yerine getirmek amacında olan ÜNAK, 2000 yılından itibaren Bilgi Dünyası adındaki yılda iki kez yayımladığı süreli yayın ile yalnızca üniversite ve araştırma kütüphanelerine değil kütüphanecilik alanının diğer konularına yönelik makaleler de yayımlamaktadır. ÜNAK, Bilgi Dünyası dergisinin dışında dernek bünyesindeki oluşumlarla birlikte çeşitli etkinliklerde bulunmakta ve her yıl gerçekleştirdiği toplantılarla mesleki gelişmelerin uygulamacılarla paylaşılmasına önemli bir rol üstlenmektedir (ÜNAK-Tarihçe, 2001).

Kütüphanecilik alanının yanı sıra arşivcilik alanında da 1998 yılında Başbakanlık Devlet Arşivleri Genel Müdürlüğü Osmanlı Arşivi çalışanları, kamu kuruluşlarında çalışanlar ve üniversitelerin ilgili bölümlerinde akademik çalışma yapan kadrolar tarafından Türk Arşivciler Derneği (TAD) kurulmuştur. TAD bu yapısı ile arşivcilik mesleği ile uğraşanların birbirleriyle etkileşimlerini sağlamayı ve mesleki paylaşımları gerçekleştirmeyi amaçlamıştır (arsivder, 2010).

TKD ve ÜNAK tarafından çıkarılan süreli yayınlar ulusal ve uluslararası indekslerde yer almakta ve literatürün gelişmesine katkı sağlamaktadırlar. Bu doğrultuda bu yayınların niteliği ve kalitesi alanın gelişimi için son derece önemli olmaktadır. Bu çalışmada Türk kütüphanecilik ve bilgibilim derneklerinden biri olan ÜNAK'ın resmi yayın organı olarak nitelendirilen ve yılda iki kez yayımlanan Bilgi Dünyası dergisinin oluşum süreci ve dergide yayımlanan bilimsel makalelerin atıf analizi yapılarak Bilgi Dünyası dergisinin bibliyometrik bir profilinin çıkarılması hedeflenmektedir.

\section{Mesleki Bir Dernek Olarak ÜNAK ve Resmi Yayın Organı: "Bilgi Dünyası"}

Türk Kütüphaneciler Derneği ile birlikte Türkiye'de kütüphanecilik ve bilgibilim alanında hizmet veren bir oluşum olan ÜNAK, üniversite kütüphanelerine özgü sorunların çeşitli platformlarda dile getirilmesini ve gerekli çözümlerin ortaya çıkarılmasını amaçlamıştır. 
Dernek bu kapsamda 9 Ağustos 1991 tarihinde merkezi Ankara'da 0639009 numara ile "Üniversite ve Araştırma Kütüphanecileri Derneği” kısa adı “ÜNAK” olarak tescil ettirerek faaliyetlerine başlamıştır (ÜNAK, 2001). 1991 yılından itibaren faaliyetlerini her yıl düzenlediği toplantılarla, çıkardığı süreli yayınlarla ve oluşturduğu GençÜNAK gibi yeni gruplarla sürdüren ÜNAK kurulduğu tarihten itibaren özgün araştırmayı özendirme ve destekleme, projeler kabul etme ve yürütme, benzer kuruluşlarla iş birliği yapma gibi birçok işlev taşımış ve günümüzde de bu işlevlerini sürdürmeye çalışmaktadır (Bulgun, 2006, s. 18).

Yukarıda belirtilen amaçlar doğrultusunda çalışmalarını yürüten ÜNAK, yayımladığı Bilgi Dünyası dergisi ile Türkiye'de bilgibilim ve kütüphanecilik alanının bilimsel boyutlarda ilerlemesine katkı sağlamaktadır. Bilgi Dünyası́nda, üniversite ve araştırma kütüphaneleri ağılıklı olmak üzere, bilgibilim, bilgi hizmetleri, bilgi ve belge yönetimine ilişkin sorunları inceleyen ve çözüm önerileri sunan Türkçe veya İngilizce özgün makalelere yer verilmektedir. Ayrıca çeşitli konularda kişisel görüşler, bilgi merkezleri ve kitap eleştirileri, haberler ve mesleki toplantı duyuruları da içerik kapsamında okuyuculara sunulmaktadır. Dergi, 2000 yılından bu yana hakemli bir dergi olarak altı ayda bir (Nisan ve Ekim) yayımlanmaktadır (ÜNAK, 2009).

Bilgi Dünyası dergisinin gelişim evrelerine baktığımızda derginin ilk sayısının 2000 yılında çıkmış olmasına karşın hazırlık sürecinin 1998 yılından itibaren iki yıl sürdüğü görülmektedir. Derginin bu süreçten sonra; 2002 yılında Ulrich's Periodicals Directory'de listelenmesi için başvurusunun yapıldığı, 2003 Ağustos ayında ULAKBiM Sosyal Bilimler Veri Tabanına kabul edildiği, 2003 yılının Aralık ayında ise Library and Information Science Abstracts'da (LISA) dizinlenmeye başladığı görülmektedir (Bahşişoğlu, Duran ve Yıldızeli, 2007, s.83). Dergi günümüzde de Index Copernicus, EBSCO Host gibi veri tabanlarında dizinlenerek varlığını sürdürmektedir. Ayrıca Bilgi Dünyası açık erişimli bir dergi olma özelliğine de sahiptir. Bu bağlamda dergi DOAJ kısaltmasıyla bilinen Directory of Open Access Journals ve E-LIS (E-Prints in Library and Information Science)'te yer almaktadır. Bunun yanı sıra yayımlanmış tüm sayılara dergi web sayfası üzerinden erişilebilmektedir (Bilgi Dünyası, 2010).

\section{Önceki Çalışmalar}

Literatürde kütüphanecilik alanında yayımlanan dergilerin bibliyometrik profillerinin saptanmasına yönelik pek çok çalışmaya rastlanmıştır.

2002 yılında yapılan bir çalışmada D-Lib Magazine dergisinin yazar karakteristikleri üzerine bir çalışma yürütülmüş ve derginin ilk 13 yılı değerlendirilmiştir. Dijital ortamda yayın hayatına başlamış (born digital) olan derginin atıflarının durumu, yazarların üretkenlikleri, cinsiyetleri, kurumları, coğrafik dağılımları gibi hususlar rapor edilmiştir (Park, 2002) Çalışmada D-Lib Magazine dergisinin 2006-2008 yılları arasında 74 disiplinlerarası alanda 50'den fazla ülkeden atıf aldığı sonucuna ulaşılmıştır. Yine 
D-Lib Magazine dergisine yönelik yapılan başka bir çalışmada dergide yayımlanan makalelerin kaynakçalarında atıf yapılan web bağlantıları incelenmiş ve bu bağlantıların erişilebilirlikleri kontrol edilmiştir. Çalışma sonucunda web bağlantılarının yaklaşık \%58'inin hatalı olduğu sonucuna ulaşıımıştır (McCown, Chan, Nelson ve Bollen, 2005).

Scientometrics dergisinin ilk 50 sayısının yazarlık / ortak yazarlık karakteristikleri konusunda incelendiği bir çalışmada derginin \%47,3 oranında kendine atıf yaptığı, en çok atıf yapılan yayınların yine Scientometrics dergisinde yayımlandığı ve yapılan yayınların konularının kütüphanecilik ve bilgibilim üzerine yoğunlaştığı sonuçlarına ulaşılmıştır (Schubert, 2002). Yine Scientometrics dergisinde yayımlanmış ilk 50 yayın üzerinde yapılan bir başka çalışmada yayınlar coğrafi, kurumsal ve ortak yazarlık yönünden değerlendirilmiş ve dergide çok yazarlı yayınların sayısında artış görüldüğü ve uluslararası işbirliği durumunun son yıllarda ivme kazandığı yorumu yapılmıştır (Dutt, Garg ve Bali, 2003).

Literatürde Journal of the American Society for Information Science and Technology (JASIST), Journal of Documentation, Libri, Library Quarterly ve Journal of Librarianship and Information Science dergileri ile ilgili bibliyometrik profil çıkarma çalışmaları da yapılmış ve dergiler bibliyometrik açılardan incelenmişlerdir (Koehler, 2001; Tsay, 2008; Nebelong-Bonnevie ve Frandsen, 2006; Wormell, 2000; Young, 2006; Furner, 2009).

Türkiye'de de son yıllarda dergilerin bibliyometrik incelemelerine yönelik çalışmalar yapılmaya başlanmıştır. Bu kapsamda Türk PsikolojiDergisi, Turkish Journal ofChemistryve Milli Folklor dergileri incelenmiş ve bibliyometrik analiz çalışmaları yürütülmüştür (Al ve Coştur, 2007; Birinci, 2008; Yalçın, 2010). Kütüphanecilik alanında yayımlanan dergilere yönelik olarak da çeşitli çalışmalar yapılmıştır. Bu çalışmalardan bir tanesi Tonta (2002) tarafından yapılan Türk Kütüphaneciliği dergisine yönelik olan çalışmadır. Bu çalışmada Türk Kütüphaneciliği'nin 1987-2001 yılları arasında yayımlanan sayıları incelenmiş ve 238 makale bibliyometrik özellikleri açısından birbirleri ile karşısıştırılmıştır. Çalışmada Türk Kütüphaneciliği dergisinde hakemli ve hakemsiz dönemlerde en sık yayın yapan yazarın Hacettepe Üniversitesi Bilgi Belge Yönetimi Bölümünden Bülent Yılmaz olduğu sonucuna ulaşılırken en çok yayın yapan kurumun Hacettepe Üniversitesi Bilgi ve Belge Yönetimi Bölümü olduğu görülmüştür. Bunun yanında en sık atıf yapılan kaynak türünün Türkçe kitaplar olduğu ve Türkçe kitapları yabancı dilde dergiler ve yabancı dilde kitapların takip ettiği gözlenmiştir. 2003 yılında düzenlenen bir toplantıda ise Bilgi Dünyası dergisinde yayımlanmış makaleler sayı ve dil gibi özellikler açısından değerlendirilmiş ve bulgular sunulmuştur (Bahşişoğlu, Duran ve Yıldızeli, 2007). Her iki kütüphanecilik dergisini de kapsayan bir diğer çalışmada Bilgi Dünyası ve Türk Kütüphaneciliği dergileri aldıkları ve birbirine yaptıkları atıflar ile bu dergilerde yapılan atıfların özellikleri açısından karşılaştırılmış, makale başına düşen atıf oranlarının benzerlik gösterdiği ve çoğunlukla kanıt gösterme amacı ile atıf yapıldığı sonucuna ulaşıımıştır (Atılgan, Atakan ve Bulut, 2008). 


\section{Amaç, Yöntem ve Kapsam}

Bu araştırmanın temel amacı Bilgi Dünyası dergisinin bibliyometrik profilinin ortaya çıkarılmasıdır. Bu amaç kapsamında aşağıdaki sorulara cevap aranmıştır;

$\diamond$ Bilgi Dünyası'nda yayımlanan makalelerin yıllara göre dağılımı nasıldır?

$\diamond$ Bilgi Dünyası'nda yayımlanan makalelerin yazar profilinin dağılımı nasıldır?

$\diamond$ Bilgi Dünyası́nda yayımlanan makalelerin konu dağılımı nasıldır?

$\diamond$ Bilgi Dünyası'nda en sık atıf yapılan kaynak türü nedir?

$\diamond$ Bilgi Dünyası'nda en sık atıf yapılan dergiler nelerdir?

$\diamond \quad$ Bilgi Dünyası'nda en sık atıf yapılan dergilerin JCR (Journal Citation Reports)'deki yeri nedir?

$\diamond \quad$ Bilgi Dünyası́nda makale yayımlayan yazarların kendine atıf oranları nasıldır?

Bu bağlamda 2000 yılından itibaren Bilgi Dünyası'nda yayımlanmış 21 sayı içinde yer alan 104 hakemli makale ve 60 görüş incelenmiş ve elde edilen bulgular sunulmuştur.

Değerlendirme kapsamında dergide yayımlanmış tüm hakemli makale ve görüşlere ait bilgiler bir Excel tablosuna aktarılmış ve sayısal hesaplamalar ile grafik ve tablolar bu tablo üzerinden gerçekleştirilmiştir.

Yayın yapan yazarların isimlerinde farklı kullanımlar (örn: Serap Kurbanoğlu - Sabriye Serap Kurbanoğlu) göze çarpmıştır. Bu farklı kullanımların sonucu değiştirmemesi için farklı yazılmış yazar isimlerinde birleştirim yapılmıştır. Benzer bir birleştirim atıf yapılan dergi isimleri için de gerçekleştirilmiştir.

Dergide yayımlanmış makalelerin konu dağılımının saptanmasına yönelik çalışmada LISA terim listesi ve Jarvelin ve Vakkari (1993) tarafından kütüphanecilik ve bilgibilime yönelik olarak hazırlanan sınıflama şeması temel alınmıştır.

Atıfların değerlendirilmesi için her bir hakemli makalenin kaynakçası tek tek incelenmiş ve bu kaynakçalar yine bir tabloya aktarılmıştır. En sık atıf yapılan dergilerin etki değerleri Journal Citation Report (JCR) veri tabanı 2009 verileri kullanılarak bulunmuştur.

\section{Bulgular ve Yorum}

\section{Makalelerin Yıllara Göre Dağılımı}

2000 yılından bugüne kadar Bilgi Dünyası dergisinde toplam 104 hakemli makale ve 60 görüş yayımlanmıştır. Yıl başına düşen ortalama hakemli makale sayısı 9,5, görüş sayısı ise 5,5 olarak hesaplanmıştır. Şekil 1'de sunulan grafikte hakemli makale ve görüşlerin sayılarının yıllara göre dağılımı gösterilmektedir (Bkz. Şekil 1). 


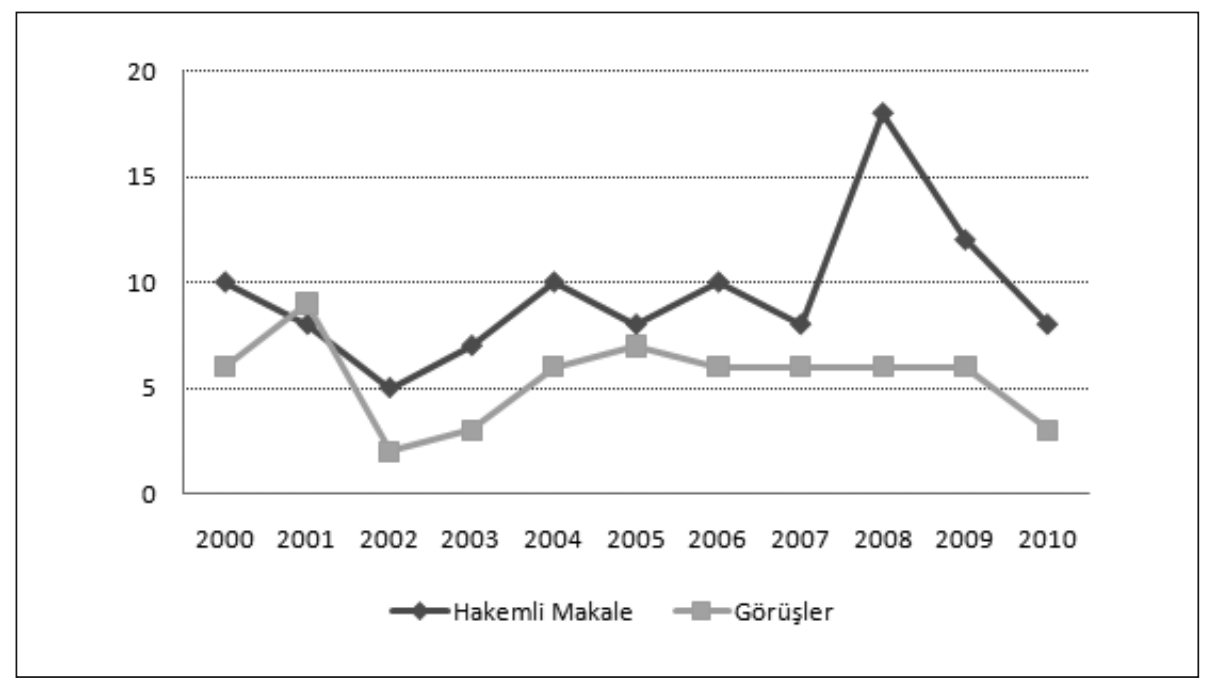

Şekil 1. Yıllara göre yayınların dağılımı

Şekil 1'de görüleceği üzere yayın hayatına yüksek hakemli makale sayısı ile başlayan Bilgi Dünyası, başlangıcındaki performansının benzerini 2004 yılında yakalamış, 2008 yılına kadar yayın sayılarında küçük dalgalanmalar görülse de önemli bir değişiklik göstermemiştir. 2008 yılına gelindiğinde yayımlanan makale sayısında büyük bir sıçrama gözlenmiştir. Yaşanan bu büyük artışı 2007 yılında Hacettepe Üniversitesi Bilgi ve Belge Yönetimi Bölümü tarafından gerçekleştirilen Değişen Dünyada Bilgi Yönetimi Sempozyumu'nda sunulan bildirilerin Bilgi Dünyası Nisan sayısında yayımlanması olarak yorumlamak mümkündür.

Bunun yanında derginin Ekim 2010 sayısı henüz yayımlanmamış olmasına karşın 2010 yılında yayımlanan makale sayısının 2005 ve 2007 yılları ile eşit, 2002 ve 2003 yıllarının üzerinde olduğu görülmüştür. 2008 yılında ULAKBiM Sosyal Bilimler Veri Tabanı'nda dizinlenmeye başlayan Bilgi Dünyası dergisinin (ULAKBiM, 2010) son iki yılda yaşadığı yayın sayısı artışının nedeninin ulusal ve uluslararası dizinlerde kalıcılı̆ı̆ını sağlamaya yönelik bir tutum olduğunu söylemek yanlış olmayacaktır.

\section{Yazar Profili}

Başlangııından bugüne Bilgi Dünyası dergisinde 39 farklı kurumdan 96 yazarın hakemli makale yayımladığı görülmülştür. En çok hakemli makale yayımlayan yazarın 11 makale ile Hacettepe Üniversitesi Bilgi ve Belge Yönetimi Bölümünden Umut Al olduğu sonucuna ulaşılırken, yine aynı bölümden Bülent Yılmaz ve Özgür Külcü en çok yayın yapmış diğer yazarlar olmuşlardır. 38 farklı kurumdan 63 yazar tarafından yayımlanan 
görüşlerde ise en çok görüş yayımlayan yazar 4 görüş ile Alan Gilchrist olmuştur. Tablo I'de en çok yayın yapan yazarlar ve yayın sayıları listelenmektedir.

Tablo I. Bilgi Dünyası'nda yayın yapan yazarların dağılımı

\begin{tabular}{lclc}
\hline \multicolumn{1}{c}{ En çok yayın yapan hakemli makale yazarları } & \multicolumn{2}{c}{ En çok yayın yapan görüş yazarları } \\
\hline Yazar & Yayın Sayısı & \multicolumn{1}{c}{ Yazar } & Yayın sayısı \\
\hline Umut Al & 11 & Alan Gilchrist & 4 \\
Bülent Yılmaz & 7 & Altan Çolakkol & 2 \\
Özgür Külcü & 6 & Beyhan Karpuz & 2 \\
H. İnci Önal & 5 & Güssün Güneş & 2 \\
Mesut Kurulgan & 5 & M. Emin Küçük & 2 \\
Nazan Özenç Uçak & 5 & Muharrem Yılmaz & 2 \\
Hayri Sever & 4 & Özden Demircioğlu & 2 \\
Hande Uzun Külcü & 3 & Pervin Dedeler Bezirci & 2 \\
Mustafa Sağsan & 3 & Ramazan Bakırcı & 2 \\
S. Serap Kurbanoğlu & 3 & Selenay Aytaç & 2 \\
Yaşar Tonta & 3 & & \\
\hline
\end{tabular}

Yazarlardan yalnızca biri ondan fazla yayın üretirken, 76 yazar yalnızca bir hakemli makale yayımlamıştır. Benzer şekilde görüşlerde de 56 yazarın yalnızca bir görüş yayımladıkları sonucuna ulaşılmıştır.

Yayınların çok yazarlılık durumu incelendiğinde bir hakemli makalenin en fazla üç yazar tarafından oluşturulduğu saptanmıştır. Üç yazarlı toplam 11 makale üretilirken, 67 makalenin ise tek yazarlı olduğu görülmüştür. Görüşlerde ise yalnızca bir yayının dört yazarlı olduğu, 45 yayının ise tek yazarlı olduğu sonucuna ulaşılmıştır.

Bu çalışma kapsamında ayrıca dergide en çok yayın yapan yazarların kurumları da incelenmiştir. Bu inceleme kapsamında yayımlanmış makale ya da görüş içinde yazarın kendini tanımladığı adres yazar kurumu olarak kabul edilmiştir. Bu bağlamda en çok yayın yapan kurumlar ve yazar sayıları Tablo II'de gösterilmektedir.

Yayın yapmak için Bilgi Dünyası dergisini seçen yazarların çoğunluğunu akademisyenler oluşturmaktadır. Araştırmamızda özellikle Hacettepe Üniversitesi ve Ankara Üniversitesi bilgi ve belge yönetimi bölümlerinde görev yapan akademisyenlerin sıklıkla Bilgi Dünyası'nda yayın yaptıkları sonucuna ulaşılmıştır. 
Tablo II. Bilgi Dünyası Dergisinde en çok yayın yapan kurumlar

\begin{tabular}{|c|c|c|c|}
\hline \multicolumn{2}{|c|}{ En çok hakemli makale yayımlayan kurum } & \multicolumn{2}{|c|}{ En çok görüş yayımlayan kurum } \\
\hline Kurum & $\begin{array}{l}\text { Yazar } \\
\text { Sayısı }\end{array}$ & Kurum & $\begin{array}{l}\text { Yazar } \\
\text { sayısı }\end{array}$ \\
\hline Hacettepe Üniversitesi (Toplam) & 28 & Hacettepe Üniversitesi (Toplam) & 12 \\
\hline H.Ü. Bilgi ve Belge Yön. Böl. & 17 & H.Ü. Bilgi ve Belge Yön. Böl. & 11 \\
\hline H.Ü. Kütüphaneleri & 4 & H.Ü. Kütüphaneleri & 1 \\
\hline H.Ü. Diğer & 7 & & \\
\hline \multirow{3}{*}{$\begin{array}{l}\text { Ankara Üniversitesi Bilgi ve Belge } \\
\text { Yön. Böl. }\end{array}$} & \multirow{3}{*}{9} & Ankara Üniversitesi (Toplam) & 4 \\
\hline & & A.Ü. Bilgi ve Belge Yön. Böl. & 3 \\
\hline & & A.Ü.Diğer & 1 \\
\hline Başkent Üniversitesi (Toplam) & 7 & & \\
\hline Başkent Üni. Kütüphanesi & 1 & & \\
\hline Başkent Üni. Diğer & 6 & & \\
\hline Anadolu Üniversitesi & 4 & & \\
\hline İstanbul Üniversitesi (Toplam) & 4 & & \\
\hline i.ü. Bilgi ve Belge Yön. Böl. & 2 & & \\
\hline i.ü. Diğer & 2 & & \\
\hline
\end{tabular}

Tablo III. En çok yayın yapan kurum türleri

\begin{tabular}{|c|c|c|c|}
\hline \multicolumn{2}{|c|}{ En çok hakemli makale yayımlayan kurum türü } & \multicolumn{2}{|c|}{ En çok görüş yayımlayan kurum türü } \\
\hline Kurum Türü & $\begin{array}{l}\text { Yazar } \\
\text { Sayısı }\end{array}$ & Kurum Türü & $\begin{array}{l}\text { Yazar } \\
\text { sayısı }\end{array}$ \\
\hline Üniversiteler (Diğer) & 38 & Üniversite kütüphaneleri & 18 \\
\hline Bilgi ve Belge Yönetimi Bölümleri & 33 & $\begin{array}{l}\text { Bilgi ve Belge Yönetimi } \\
\text { Bölümleri }\end{array}$ & 14 \\
\hline Üniversite kütüphaneleri & 7 & $\begin{array}{l}\text { Kamu kurumları ve onların } \\
\text { kütüphaneleri }\end{array}$ & 8 \\
\hline Yabancı üniversiteler & 7 & Yabancı üniversiteler & 7 \\
\hline Kamu kurumları ve onların kütüphaneleri & 4 & $\begin{array}{l}\text { Özel sektör kurumları ve onların } \\
\text { kütüphaneleri }\end{array}$ & 5 \\
\hline $\begin{array}{l}\text { Özel sektör kurumları ve onların } \\
\text { kütüphaneleri }\end{array}$ & 3 & Üniversiteler (Diğer) & 5 \\
\hline Arşiv & 2 & Okul kütüphaneleri & 3 \\
\hline Okul Kütüphaneleri & 1 & Yabancı özel sektör kurumları & 3 \\
\hline Yabancı özel sektör kurumları & 1 & & \\
\hline
\end{tabular}


Bu çalışma için yapılan bir diğer sınıflandırma da ise yayın yapan kurumların niteliği göz önüne alınmıştır. Bu kapsamda en çok yayın yapan kurumların türlerine göre yazar sayıları Tablo III'de görülmektedir.

Üniversitelerde yer alan Bilgi ve Belge Yönetimi bölümleri ile bu bölümler ve kütüphaneler dışında kalan diğer bölümlerden akademisyenlerin hakemli makale yazma eğiliminde oldukları görülürken, üniversite kütüphanecilerinin görüş yayımlamayı daha sıklıkla tercih ettikleri gözlenmiştir. Bunun yanında yabancı üniversiteler ve kurumlardan kişilerin Bilgi Dünyası dergisinde yüksek oranda olmasa da yayın yaptıkları sonucuna ulaşılmıştır.

\section{Makalelerin Konu Dağılımı}

Bilgi Dünyası dergisinin hakemli makaleler bölümünde yer alan 104 makalenin konuları kullanılan anahtar sözcükler dikkate alınarak analiz edilmiştir. Yapılan analizlere göre 104 makalede toplam 419 anahtar sözcük kullanılmıştır. Bu sayı makale başına yaklaşık dört anahtar sözcüğün kullanıldığını göstermektedir. Makalelerin konu dağılımları belirlenirken anahtar sözcükler ve makaleler, LISA terim listesi ile Jarvelin ve Vakkari (1993) tarafından kütüphanecilik ve bilgibilime yönelik olarak hazırlanan sınıflama şemasına göre değerlendirilmiş, ülke adları, kurum adları gibi anahtar sözcükler dikkate alınmamıştır. Değerlendirmelere göre Bilgi Dünyası dergisinde yayımlanan makalelerde kullanılan anahtar sözcükler doğrultusunda sıklıkla ele alınan konular Tablo IV'de verilmektedir.

Tablo IV. Makalelerin Konulara Göre Dağılımı

\begin{tabular}{lc}
\hline Konu & Anahtar Sözcük Olarak Kullanılma Sayısı \\
\hline Bilgi depolama ve bilgi erişim & 45 \\
Kütüphane kullanımı ve bilgi hizmetleri & 29 \\
Bilgi yönetimi & 21 \\
Bilgi kaynakları ve kanalları & 21 \\
Mesleki alanlar & 21 \\
Atıf örüntüleri ve yapıları (Bibliyometri) & 18 \\
\hline
\end{tabular}

Tablo IV'den anlaşılacağı gibi, bilgi depolama ve bilgi erişim konusu makalelerde çoğunlukla ele alınan konudur. Bu konu kapsamında bilgi erişim konusu (24 kez) ve bilginin depolandığı alanlar olarak görülen bilgi sistemleri (21 kez) makalelerde sıklıkla ele alınmıştır. Diğer yandan bilgi merkezlerinin kullanımına yönelik çalışmalar makalelerde ele alınan ikinci konu olmuştur. Bu konu kapsamında ise sırasıyla üniversite kütüphaneleri (13 kez), genel olarak kütüphaneler (8 kez), halk kütüphaneleri (5 kez), tıp kütüphaneleri (1 kez), okul kütüphaneleri (1 kez) ve müzeler (1 kez) ile ilgili makaleler Bilgi Dünyası dergisinde yer almıştır. Derginin çıkış yılı olan 2000 yılından bu yana yayımlanan makalelerin konusal olarak dağılımına bakıldığında, gelişen teknolojiler ve yeni uygulamaların çalışmalara yeni boyutlar kazandırdığı ve konuların bu yönde 
değişiklik gösterdiği gözlenmektedir. Buna örnek olarak ilk yıllarda internet, internette bilgi erişim gibi konuların ele alındığı makalelerin, ilerleyen yıllarda ise içerik tabanlı görüntü erişimi, kavram tabanlı bilgi erişim, metin gruplama gibi konuları içeren makalelerin yoğunlaştığı görülmektedir. Öte yandan bilgi okuryazarlığı, bibliyometri, okuma alışkanlığı gibi konuların farklı dönemlerde boyut değiştirerek ele alındığı görülmüştür. 2005 yılından bu yana çıkan hakemli yazıların konularına bakıldığında ise belge yönetimi konusununun anahtar kelime olarak verildiği makale sayısının (8 kez) çoğunlukta olduğu, bunu bibliyometri konusunun (5 kez) izlediği dikkati çekmektedir.

\section{Atıf Durumu}

Bu çalışma kapsamında 104 hakemli makalenin kaynakçaları incelenmiş, en sık atıf yapılan kaynak türü ve en sık atıf yapılan dergiler analiz edilmiştir. Bu kapsamda toplam 3042 atıf değerlendirilmiş ve makale başına düşen atıf sayısı 29,3 (SS: 6,2) olarak saptanmıştır. Bir makalede yapılmış en yüksek atıf sayısı 90 iken, en az atıf yapan makalede yalnızca bir atıf olduğu görülmüştür.

\section{a. En sık atıf yapılan kaynak türleri}

Yapılan araştırmada yazarların en sık atıf yaptıkları kaynak türünün dergiler olduğu sonucuna ulaşılmıştır. Yapılan toplam 3042 atıfın üçte birini dergiler oluştururken bunu kitaplar (772 kez) ve elektronik kaynaklar (567 kez) takip etmiştir. En sık atıf yapılan dördüncü kaynak olarak sunumlar, kanunlar, yönetmelikler, düzenlemeler, standartlar ve Resmi Gazete gibi kaynakları içeren diğer seçeneği izlemiştir (Bkz. Tablo V).

Tablo V. En sık atıf yapılan kaynak türleri

\begin{tabular}{lc}
\hline Atıf yapılan kaynak türü & Kaynakçadaki atıf sayısı \\
\hline Dergi & 1056 \\
Kitap & 772 \\
Elektronik kaynak & 567 \\
Diğer & 218 \\
Bildiri kitabı & 186 \\
Kitap içinde bölüm & 138 \\
Tez & 105 \\
\hline Toplam & 3042 \\
\hline
\end{tabular}

\section{b. En sık atıf yapılan dergiler}

En sık atıf yapılan kaynak türünün dergiler olmasından hareketle en sık atıf yapılan dergiler de çalışma kapsamında incelenmiştir. Bilgi Dünyası dergisi tarafından en sık atıf yapılan derginin Türk Kütüphaneciliği (\%19) dergisi olduğu ve bunu Scientometrics (\%8) ile Bilgi Dünyası (\%7) dergilerinin takip ettiği görülmüştür (Bkz. Şekil 2). 


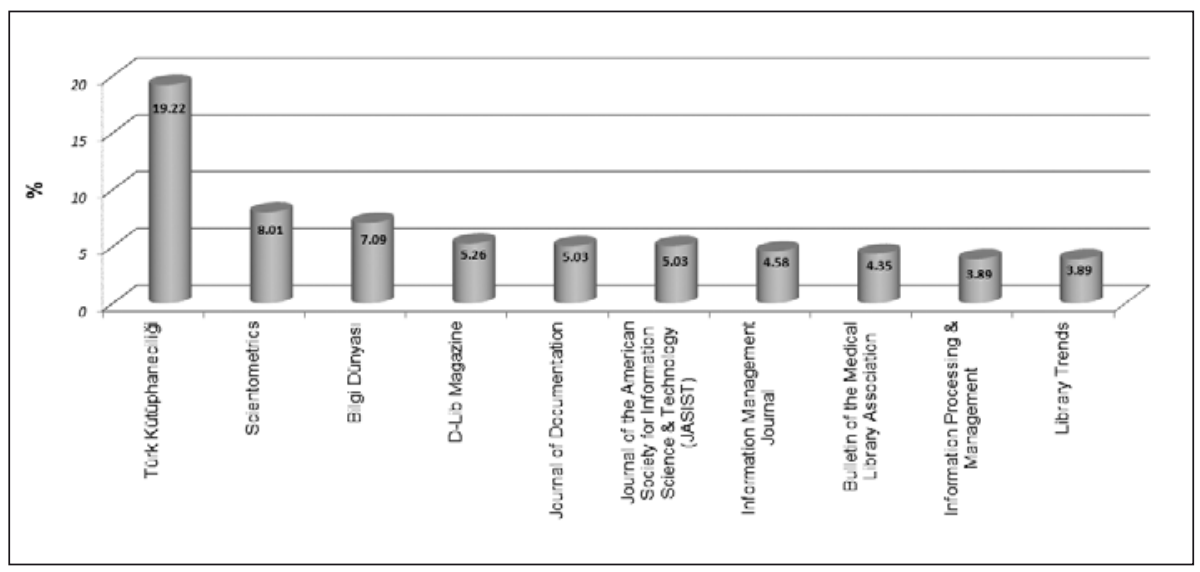

Şekil 2. En Sık Atıf Yapılan Dergiler

\section{En sık atıf yapılan dergilerin JCR'deki yeri}

$J C R$, dünyanın önde gelen dergilerinin atıf verilerine dayanan ve bu atıf verileri üzerinden nicel verileri sunan bir değerlendirme aracıdır (Thomson Reuters, 2010). JCR'nin sunduğu nicel verilerden biri belirli bir yılda yayımlanmış makalelerin ilerleyen yıllarda aldıkları ortalama atıf oranını gösteren etki faktörü (impact factor) değeridir. Etki faktörü belirli bir makalenin atıf performansından ziyade bütün derginin atıf performansına dair bir göstergedir (Testa, 2008). Bu çalışma kapsamında Bilgi Dünyası tarafından sıklıkla atıf yapılan dergilerin $J C R$ 'deki yeri belirlenerek yazarların atıf tercihlerinde dergi etki faktörü değerlerini göz önüne alıp almadıkları araştırılmıştır. Bulgulara göre Bilgi Dünyası dergisindeki yayınlarda en sık atıf yapılan ilk 10 derginin altısının JCR kapsamında yer aldığı saptanmıştır. Ancak $J C R^{\prime}$ de kütüphanecilik ve bilgibilim başlığı altında yer alan en yüksek etki faktörüne sahip ilk 10 dergi göz önüne alındığında Bilgi Dünyası dergisindeki yayınlarda yalnızca Scientometrics ve Journal of the American Society for Information Science \& Technology (JASIST) dergilerine atıf yapıldığı görülmüştür (Bkz. Tablo VI). Bu sonuçlardan hareketle Bilgi Dünyası yazarlarının $J C R$ etki faktörü değerlerini dikkate almadığı söylenebilir. Ancak bu durumun, $J C R^{\prime}$ de kütüphanecilik ve bilgibilim başlığı altında yer alan bazı yayınların (örn. Journal of Informetrics) yüksek etki faktörüne sahip olmasına karşın son birkaç yıl içerisinde yayımlanmaya başlamış olmasından ve/veya bazı yayınların kapsam olarak bilgibilim ve kütüphanecilik alanının özel konularını içermesinden kaynaklanabileceği konusu dikkate alınmalıdır. 
Tablo VI. En sık atıf yapılan dergiler ve etki faktörleri

\begin{tabular}{|c|c|c|c|}
\hline \multicolumn{2}{|c|}{$\begin{array}{l}\text { Bilgi Dünyası'nda en sık atıf yapılan } \\
\text { kütüphanecilik dergileri ve etki faktörleri }\end{array}$} & \multicolumn{2}{|c|}{$\begin{array}{l}J C R^{\prime} \text { ye göre en yüksek etki faktörüne sahip } \\
\text { kütüphanecilik dergileri }\end{array}$} \\
\hline Dergi Adı & $\begin{array}{c}\text { Etki } \\
\text { Faktörüu }\end{array}$ & Dergi Adı & $\begin{array}{l}\text { Etki } \\
\text { Faktörü }\end{array}$ \\
\hline Türk Kütüphaneciliği & - & MIS Quarterly & 4,485 \\
\hline Scientometrics & 2,167 & $\begin{array}{l}\text { Journal of the American } \\
\text { Medical Informatics Association }\end{array}$ & 3,974 \\
\hline Bilgi Dünyası & - & $\begin{array}{l}\text { Journal of Computer-Mediated } \\
\text { Communication }\end{array}$ & 3,639 \\
\hline D-Lib Magazine & - & Journal of Informetrics & 3,379 \\
\hline Journal of Documentation & 1,405 & $\begin{array}{l}\text { Annual Review of Information } \\
\text { Science and Technology }\end{array}$ & 2,929 \\
\hline JASIST & 2,300 & $\begin{array}{l}\text { International Journal of } \\
\text { Computer-Supported } \\
\text { Collaborative Learning }\end{array}$ & 2,692 \\
\hline Information Management Journal & - & JASIST & 2,300 \\
\hline $\begin{array}{l}\text { Bulletin of the Medical Library } \\
\text { Association }\end{array}$ & 0,880 & Information \& Management & 2,282 \\
\hline $\begin{array}{l}\text { Information Processing \& } \\
\text { Management }\end{array}$ & 1,783 & $\begin{array}{l}\text { Journal of the Association for } \\
\text { Information Systems }\end{array}$ & 2,246 \\
\hline Library Trends & 0,393 & Scientometrics & 2,167 \\
\hline
\end{tabular}

\section{Kendine Atıf (Öz Atıf) Durumu}

Literatürde kendine atıf genellikle atıf yapılan ve atıf yapan makalelerde en az bir yazarın ortak olarak bulunması şeklinde tanımlanmaktadır (Aksnes, 2003). Tüm atıflar içinde kendine atıfların sayısı önemli bir yer tutmakta ve bu nedenle litetatürde kendine atıflar ile ilgili farklı yaklaşımlar yer almaktadır. Kimi araştırmacılara göre kendine atıf, bireysel araştırmaların doğası gereği normal ve kabul edilebilir bir prosedür olarak açıklanabilirken (Phelan, 1999), kimilerine göre yazarlar kendi bilimsel otoritelerini yaratmak ve çalışmalarını görünür hale getirmek için kendine atıf yapmaktadırlar (Lawani, 1982). Tüm bunlardan hareketle bu çalışma kapsamında Bilgi Dünyası'nda yayın yapan yazarların kendine atıf durumları incelenmiş ve sonuçları sunulmuştur (Bkz. Tablo VII). 
Tablo VII. Yazarların kendine atıf durumları

Bir yayında en fazla kendine atıf yapan yazarlar
Toplamda en fazla kendine atıf yapan yazarlar

\begin{tabular}{lcccc}
\hline Yazar adı & $\begin{array}{c}\text { Kendine atıf } \\
\text { sayısı }\end{array}$ & Yazar adı & $\begin{array}{c}\text { Kendine atıf } \\
\text { sayısı }\end{array}$ & $\begin{array}{c}\text { Yazarların } \\
\text { Yayın Sayıları }\end{array}$ \\
\hline Hayri Sever & 10 & Yaşar Tonta & 15 & 3 \\
Nazmi Kozak & 8 & Hayri Sever & 11 & 4 \\
Yaşar Tonta & 8 & H. Innci Önal & 9 & 5 \\
H.Inci Önal & 6 & Nazmi Kozak & 8 & 1 \\
Yaşar Tonta & 4 & Umut Al & 8 & 11 \\
\hline
\end{tabular}

Bilgi Dünyası dergisinde yayın yapan yazarlardan bir yayınında en fazla kendine atıf yapan yazarın Hayri Sever olduğu görülmüştür. Yaşar Tonta ise toplamda en fazla kendine atıf yapan yazar olmuştur. Kapsamlı bir atıf analizi çalışması ile yazarların makalelerinde dışarıdan aldıkları atıfların incelenmesi gerekmektedir. Bu konu bir başka çalışmanın temelini oluşturabilir.

\section{Sonuç ve Değerlendirme}

Başlangıcından günümüze Bilgi Dünyası dergisi'nin bibliyometrik profilinin incelendiği bu çalışmada derginin yazar profili, atıf durumu ve yapılan yayınların konu dağılımı gibi çeşitli başlıklar incelenmiş ve sonuçları sunulmuştur. Bu yayının hazırlandığı Ekim 2010 tarihine kadar dergide 104 hakemli makale ve 60 görüş yayımlanmıştır. En yüksek hakemli makale sayısına 2008 yılında ulaşılmıştır. 2004 yılının ardından 2008 yılına kadar yayımlanan hakemli makale ve görüşlerin sayılarında önemli bir değişiklik gözlenmemiştir. Ancak 2008 yılında yayımlanan özel sayının etkisiyle yıl içerisindeki her iki sayıda da hakemli makale sayısı artış göstermiştir. 2008 yılı sonrasında ise yayımlanan makale sayısında düşüş olmasına karşın önceki yıllara göre daha fazla hakemli makale yayımlanmışıı. Bu durumda derginin çıkış süreleri arasındaki zaman aralığından ve indekslendiği veri tabanlarının getirdiği ölçütlerden de kaynaklanabilmektedir.

Akademisyenlerin çoğunlukla yayın yaptığı dergide, en fazla yayın yapan yazarın 11 makale ile Umut Al olduğu sonucuna ulaşılımıştır. Umut Al, bu 11 makalede toplam 357 atıf yapmış ve bu atıfların 8'ini kendine atıfları oluşturmuştur. Umut Al'ı yayın sayısı açısından Bülent Yılmaz ve Özgür Külcü takip etmiştir. Bilgi Dünyası dergisini seçen yazarların çoğunluğunu akademisyenler oluşturmaktadır. 
Kurumsal açıdan bakıldığında ise Hacettepe Üniversitesi ve Ankara Üniversitesi bilgi ve belge yönetimi bölümlerindeki akademisyenlerin Bilgi Dünyası́nda sıklıkla yayın yaptıkları dikkati çekmektedir. Çalışma sonucunda elde edilen bir diğer unsur ise akademisyenlerle, uygulamacılar arasındaki yayın farklılığıdır. Bulgulardan hareketle akademisyenlerin çoğunlukla hakemli, uygulama alanında çalışanların ise görüşler bölümünde yayın yaptıkları görülmektedir.

Yazarlar tarafından sıklıkla tercih edilen konunun bilgi depolama ve bilgi erişim olduğu görülmüştür. Bunları kütüphane kullanımı ve bilgi hizmetleri konuları takip etmiştir.

En sık atıf yapılan dergi yine bir kütüphanecilik derneği yayını "Türk Kütüphaneciliği" olurken, uluslararası düzeyde en çok atıf yapılan derginin "Scientometrics" olduğu sonucuna ulaşılmıştır. Bu durumun nedeninin Bilgi Dünyası dergisinde yer alan makalelerin çoğunluğunun Türkçe olması ve kapsamı itibarıyla "Türk Kütüphaneciliği" dergisinin 1952'den bu yana büyük bir yayın birikimine sahip olması söylenebilir. Bunun yanında yazarların atıf yapacakları dergilerin seçiminde $J C R$ etki faktörünün büyük bir etkisinin olmadığı; JCR'de yüksek etki faktörüne sahip dergilerin kapsam olarak farklılık gösterdiği ve bu sıralamadaki bazı dergilerin yayın hayatına son birkaç yıl içerisinde başladıkları gözlenmiştir.

Bu çalışma ile Bilgi Dünyası dergisinin konusal yönelimi, yayın yapan yazarların durumları ve Bilgi Dünyası'nda atıf yapılan kütüphanecilik dergilerinin atıf sıklıkları ve etki faktörü değerleri incelenerek derginin başlangıcından bugüne bibliyometrik profili ortaya koyulmaya çalışılmıştır. Çalışma sonuçlarından hareketle ileride yapılacak ve Türk kütüphaneciliğinin tamamını kapsayacak (diğer dergiler, tezler vb.) bir ortak atıf analizi ile yalnızca Bilgi Dünyası́nın değil Türk kütüphanecilik literatürünün de profilinin çıkarılması mümkün olabilecektir.

\section{Kaynakça}

Aksnes, D.W. (2003). A Macro study of self-citation. Scientometrics, 56(2), 235-246.

Al, U. ve Coştur, R. (2007). Türk Psikoloji Dergisi'nin bibliyometrik profili. Türk Kütüphaneciliği, 21(2), 142-163.

Arsivder. (2010). Türk Arşivciler Derneği web sitesinden 10 Ağustos 2010 tarihinde http://www. arsivder.org.tr/Alt-Kategori.asp?id=124\&grup=Amaç ve Faaliyet Alanı adresinden erişildi.

Atılgan, D., Atakan, C., ve Bulut, B. (2008). Türkçe kütüphanecilik dergilerinin atıf analizi. Türk Kütüphaneciliği, 22(4), $392-413$.

Bahşişoğlu, H.K., Duran, Z.C. ve Yıldızeli, A. (2007). Mesleki ve bilimsel bir dergi: Bilgi Dünyası. Aytaç Yıldızeli ve Hatice Kübra Bahşişoğlu (Ed.), Adile Günden Anısına Armağan: Bilgiye Erişimde Değişen Yollar ve II Tıbbi Bilgi Yönetimi ve Teknolojileri Sempozyumu içinde (ss.78-88). Ankara: ÜNAK. 
Bilgi Dünyası. (2010). 10 Ağustos 2010 tarihinde http://www.unak.org.tr/BilgiDunyasi/hakkimizda. $\mathrm{htm}$ adresinden erişildi.

Birinci, H.G. (2008). Turkish Journal of Chemistry'nin bibliyometrik analizi. Bilgi Dünyası, 9(2), 348369.

Bulgun, B. (2006). ÜNAK; dün, bugün, yarın. Aytaç Yıldızeli, Hatice Kübra Bahşişoğlu (Ed.), ÜNAK'05: Bilgi Hizmetlerinin Organizasyonu ve Pazarlanması Sempozyumu bildirileri içinde (ss. 18 - 34). İstanbul: Kadir Has Üniversitesi.

Dutt, B., Garg, K.J. ve Bali, A. (2003). Scientometrics of the international journal: Scientometrics. Scientometrics, 56(1), 81-93.

Furner, J. (2009). Forty years of the Journal of Librarianship and Information Science: A quantitative analysis, part I. Journal of Librarianship and Information Science, 41(3), 149-172.

Jarvelin, K. ve Vakkari, P. (1993). Evolution of library and information science 1965-1985: Content analysis of journal articles. Information Processing \& Management 29(1), 129-144.

Koehler, W. (2001). Information science as "Little Science": The implications of a bibliometric analysis of the Journal of the American Society for Information Science. Scientometrics, 51(1), 117-132.

Lawani, S.M. (1982). On the heterogeneity and classification of author self-citations. Journal of the American Society for Information Science, 33, 281-284

McCown, F., Chan, S., Nelson M.L. ve Bollen, J. (2005). The Availability and persistence of web references in D-Lib Magazine. 5th International Web Archiving Workshop (IWAW05), Viyana, Avusturya,

Nebelong-Bonnevie, E. ve Frandsen, T. F. (2006). Journal citation Identity and journal citation image: A portrait of the Journal of Documentation. Journal of Documentation, 62(1), 30-57.

Park, T.K. (2002). D-Lib Magazine: Its first 13 years. D-Lib Magazine, 16(1-2).

Phelan, T.J. (1999). A compendium of issues for citation analysis. Scientometrics, 45, 117-136

Schubert, A. (2002). The Web of Scientometrics: A statistical overview of the first 50 volumes of the journal. Scientometrics, 53(1), 3-20.

Testa, J. (2008). Bilimsel dergilerin etki faktörlerinin saptanması ve atıf indeksleri için önemi. Ulusal Akademik Yayıncılık 2008 toplantısında sunulan bildiri.

Thomson Reuters. (2010). Journal Citation Reports. 7 Eylül 2010 tarihinde http://thomsonreuters. com/products_services/science/science_products/a-z/journal_citation_reports?parentKey= 591283,605631 adresinden erişildi.

Tonta, Y. (2002). Türk Kütüphaneciliği dergisi, 1987-2001. Türk Kütüphaneciliği, 16(3), 282-320.

Torun, O. (2003). Yeni bir mesleki oluşum: Okul Kütüphanecileri İstanbul Grubu [OKiG]. Türk Kütüphanecilği, 17(1), 55 - 68.

Tsay, M. (2008). Journal bibliometric analysis: A case study on the JASIST. Malaysian Journal of Library \& Information Science, 13(2), 121-139.

Türk Kütüphaneciler Derneği. (2010). 13 Ağustos 2010 tarihinde http://www.kutuphaneci.org.tr/ index.php?option=com_content\&view=article\&id=46\&ltemid=78 adresinden erişildi. 
Türk Kütüphaneciliği. (2010). 13 Ağustos 2010 tarihinde http://tk.kutuphaneci.org.tr/index.php/tk adresinden erişildi.

ULAKBIM. (2010). Sosyal Bilimler Veri Tabanına Giren Dergi Listesi (2008). 25 Ekim 2010 tarihinde http://www.ulakbim.gov.tr/cabim/vt/uvt/sbvt/uvt_journal_index.php?the_db=4\&the_ year=2008 adresinden erişildi.

ÜNAK. (2009). Bilgi Dünyası: hakkımızda. 24 Ağustos 2010 tarihinde http://www.unak.org.tr/ BilgiDunyasi/hakkimizda.htm adresinden erişildi.

ÜNAK - Tarihçe. (2001). Üniversite ve Araştırma Kütüphanecileri Derneği. 10 Ağustos 2010 tarihinde http://www.unak.org.tr/tarih.htm adresinden erişildi.

Wormell, I. (2000). Libri's golden jubilee in a bibliometric mirror. Libri, 50, 75-84.

Yalçın, H. (2010). Millî Folklor Dergisinin bibliyometrik profili (2007-2009). Millî Folklor, 22(85), 205211.

Young, A.P. (2006). Library Quarterly, 1956-2004: An exploratory bibliometric analysis. Library Quarterly, 76(1), 10-18. 